\section{WATER MITES ASSOCIATED WITH THE FRESH WATER MUSSEL LAMELLIDENS MARGINALIS (PELECYPODA: UNIONIDAE)}

\section{C.C. John ${ }^{1}$ and N.D Inasu ${ }^{2}$}

${ }^{1}$ Department of Zoology, St. Thomas College Thrissur, Kerala, India ${ }^{2} \mathrm{Head}$ of the Department of Zoology, Christ College Irinjalakuda, Thrissur, India

web supplement

Water mites show a series of extensive adaptive radiation and occur in most fresh water habitats. Some members of the genus Unionicola parasitic on fresh water mussel are known for their unusual behaviour. They are known to spend only the transforming stages in their molluscan host while others are permanent internal parasites (Baker, 1991). These mites are unique in that they spend part of their life cycle as larval parasites on chironomids and as nymphs and adults living symbiotically within fresh water molluscs. Mitchell (1965) made observations on the populations of Unionicola fossulata (Walcot) in lake Michigan and found that $90 \%$ of their host Lampsilis siliquoidea were infected with $U$. fossulata, and most parasitized hosts carried only one or two female mites with one male. Baker (1987) studied the life history of Unionicola ypsilophora and observed seasonal variations in the number of nymphs of $U$. ypsilophora in an individual of Anodonta cygnea. Davids et al. (1988) made observations that males of U. ypsilophora displayed territorial behaviour. They reported that males fight with other males resulting in only one male per host. Majumder and Paul (1988) studied the development of Unionicola sp. on Lamellidens marginalis in West Bengal. Since no work has been done on water mites associated with Lamellidens marginalis in Kerala the present study was taken up to study the presence and abundance of the dominant species.

Fresh water mussels were collected from four different sites: Alappad, Pullazhy, Ambaloore and Chavakkad in Thrissur district, Kerala. In order to study in detail the occurrence and infestation of mites in L. marginalis, periodic collections of 20 mussels of various sizes were made every two months in Pullazhy. Eight such collections were made from August 2000 to October 2001. All hosts were examined by cutting the adductor muscle and the shells opened. The mantle, gill, and body surface were examined with the help of a hand lens for the presence of adult mites and their nymphs (Image $1^{\mathrm{w}}$ ). They were transferred into a watch glass with the help of a medicine dropper and counted. The adult mites and nymphs collected from each fresh water mussel were preserved in Koenike's fluid separately. The identification of the adult mites were made after clearing and mounting in glycerin jelly. Also, the percentage of occurrence of infection in the mussels due to the mites was examined.

Four species of water mites Unionicola diversipes, $U$. brandti, $U$. scutigera, and females of $U$. kantaka were found in the fresh water mussel L. marginalis examined at the four sites
(Table 1). The frequency of occurrence of water mites in $L$. marginalis varied from 0-4 per mussel. Female U. kantaka has not been reported elsewhere so far. On examination of 160 mussels at Pullazhy alone a total of 270 adult mites and 3595 mite nymphs were counted and $U$. brandti (218) was found to be the dominant species followed by $U$. diversipes (35) and $U$. scutigera (17). Male and female mites were found in all the bimonthly collections of the year and the population of nymphs was observed highest during the month of April (Table 2). The percentage of incidence of infection in the 160 mussels examined was found to be $78.13 \%$ for $U$. brandti, $12.5 \%$ for $U$. diversipes, and $6.25 \%$ for U. scutigera. $96.88 \%$ of the total collection of fresh water mussels was found infected with any one of these mites (Table 3).

The present study shows the association between $U$. diversipes, $U$. brandti and $U$. scutigersa with Lamellidens marginalis. In all these mites the number of adults per host, always kept in check, though large number of nymphs present.

\section{REFERENCES}

Baker, R.A. (1987). Aspects of the life history of Unionicola ypsilophora (Bonz, 1783). The Naturalist 112(981): 53-58.

Baker, R.A. (1991). Development and life history strategies in mussel mites (Hydrachnellidae: Unionicolidae). In: Schuster, R. and P.W. Murphy (eds.). The Acari Reproduction, Development and Life History Strategies. Chapman and Hall.

Davids, C., H. Johanna, and R.V. Dimock, Jr. (1988). Competitive exclusion, harem behaviour and host specificity of the water mite Unionicola ypsilophora (Hydrachnellae, Acari) inhabiting Anodonta cygnea (Unionidae). Int. Revue Ges. Hydrobiologia 73(6): 651-657.

Majumder, M.Z.R. and S.G. Paul, (1988). Adaptations of Unionicola sp. a freshwater mite on Lamellidens marginalis from Bengal. Bicovas 1: 191-202.

Mitchel, R. (1965). Population regulation of a water mite parasitic on Unionid Mussels. Journal of Parasitology 51(6): 990-996.

\section{ACKnowledgement}

The authors wish to record the help rendered by Dr. Malcom. F. Vidrine, Louisiana State University, USA in identifying the species.

Table 1. Water mites collected from L. marginalis from Alappad, Pullazhy, Ambaloore and Chavakkad in Thrissur district, Kerala.

\begin{tabular}{|c|c|c|c|c|c|c|c|c|}
\hline \multirow[t]{2}{*}{ Species } & \multicolumn{2}{|c|}{$\begin{array}{l}\text { Alappad } \\
\text { 12.viii.96 } \\
\text { (10) }\end{array}$} & \multicolumn{2}{|c|}{$\begin{array}{l}\text { Pullazhy } \\
15 . v i i i .96 \\
\text { (8) }\end{array}$} & \multicolumn{2}{|c|}{$\begin{array}{l}\text { Ambaloore } \\
20 . v i i i .2000 \\
(10)\end{array}$} & \multicolumn{2}{|c|}{$\begin{array}{l}\text { Chavakkad } \\
25 . v i i i .2000 \\
\text { (8) }\end{array}$} \\
\hline & M & $\mathbf{F}$ & M & $\mathbf{F}$ & M & $\mathbf{F}$ & M & $\mathbf{F}$ \\
\hline Unionicola diversipes & 4 & 13 & 0 & 1 & 0 & 0 & 0 & 0 \\
\hline Unionicola brandti & 1 & 1 & 2 & 5 & 6 & 6 & 6 & 4 \\
\hline Unionicola scutigera & 3 & 4 & 1 & 1 & 1 & 1 & 0 & 0 \\
\hline Unionicola kantaka & 0 & 0 & 1 & 1 & 0 & 0 & 0 & 0 \\
\hline Total & 8 & 18 & 4 & 8 & 7 & 7 & 6 & 4 \\
\hline
\end{tabular}

Figures in parentheses indicate number of mussels examined.
${ }^{\mathrm{w}}$ see Image 1 of mites in the mantle cavity of Lamellidens marginalis, in the web supplement at www.zooreach.org 
Table 2. Consolidated account of the three species of water mites - U. diversipes, $\mathrm{U}$. brandti and $\mathrm{U}$. scutigera and their nymphs collected from Lamellidens marginalis during August 2000 to October 2001 from Pullazhy Thrissur. (sample size 20)

\begin{tabular}{|c|c|c|c|c|c|c|c|c|}
\hline Month & $\begin{array}{c}\text { U.dive } \\
\mathbf{M}\end{array}$ & $\begin{array}{l}\text { rsipes } \\
\text { F }\end{array}$ & $\begin{array}{c}\text { U.bra } \\
\mathrm{M}\end{array}$ & $\begin{array}{l}\text { andti } \\
\mathrm{F}\end{array}$ & $\begin{array}{c}\text { U.scu } \\
\text { M }\end{array}$ & $\begin{array}{l}\text { tigera } \\
\text { F }\end{array}$ & $\begin{array}{l}\text { Total } \\
\text { A }\end{array}$ & $\begin{array}{l}\text { Total } \\
\mathbf{N}\end{array}$ \\
\hline Aug-00 & 4 & 2 & 14 & 14 & 1 & 1 & 36 & 315 \\
\hline Oct-00 & 1 & 1 & 11 & 14 & 3 & 2 & 32 & 320 \\
\hline Dec-00 & 6 & 7 & 13 & 14 & 1 & 0 & 41 & 445 \\
\hline Feb-01 & 2 & 2 & 14 & 15 & 1 & 1 & 35 & 570 \\
\hline Apr-01 & 1 & 0 & 11 & 7 & 0 & 0 & 19 & 1125 \\
\hline Jun-01 & 1 & 1 & 19 & 19 & 0 & 0 & 40 & 80 \\
\hline Aug-01 & 1 & 1 & 16 & 15 & 2 & 2 & 37 & 365 \\
\hline Oct-01 & 3 & 2 & 10 & 12 & 2 & 1 & 30 & 375 \\
\hline Total & 19 & 16 & 108 & 110 & 10 & 7 & 270 & 3595 \\
\hline
\end{tabular}

Table 3. Percentage of occurrence of infection in Lamellidens marginalis by $\mathrm{U}$. diversipes, $\mathrm{U}$. brandti or $\mathrm{U}$. scutigera in the 160 specimens studied.

\begin{tabular}{lllllllllll}
\hline $\begin{array}{l}\text { Name of the } \\
\text { water mite }\end{array}$ & viii.00 & x.00 & xii.00 & ii.01 & iv.01 & vi.01 & viii.01 & x.01 \\
\hline U.diversipes & 4 & 1 & 7 & 2 & 1 & 1 & 1 & 3 & $\begin{array}{l}\text { \% of } \\
\text { infection }\end{array}$ \\
U.brandti & 15 & 16 & 14 & 15 & 13 & 19 & 18 & 15 & 78.13 \\
U.scutigera & 2 & 2 & 1 & 1 & 0 & 0 & 2 & 2 & 6.25 \\
\hline
\end{tabular}

M - Male; F- Female; A - Adult; N - Nymph

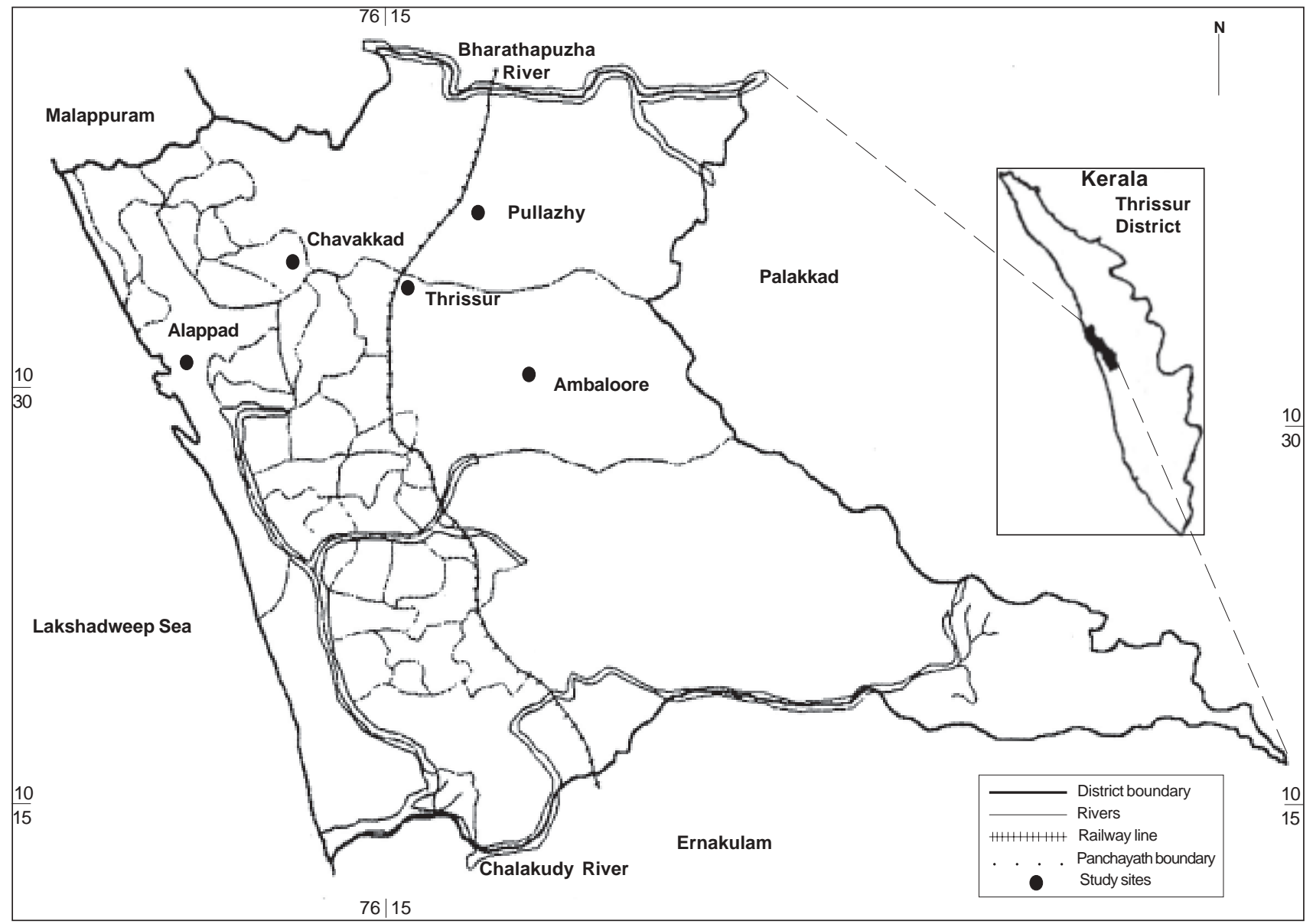

Figure 1. Map of Thrissur district - Showing the places of collection 